\title{
Pola Penataan Ruang Layanan Publik yang Smart, Berdasarkan Kajian Okupansi dan Attachment Pengguna (Objek Kasus : Ruang Layanan Publik di Kantor / Dinas di Pemerintah Kota Surabaya)
}

\author{
Susy Budi Astuti ${ }^{1}$, Mahendra Wardhana ${ }^{2}$, Prasetyo Wahyudie ${ }^{3}$, Lea Kristina \\ Anggraeni $^{4}$ \\ 1,2,3,4 Departemen Desain Interior, FDKBD, Institut Teknologi Sepuluh Nopember, Surabaya \\ ${ }^{1}$ susy@interior.its.ac.id
}

\begin{abstract}
ABSTRAK
Ruang layanan publik kantor identik dengan pintu gerbang imej layanan. Secara umum ruang layanan publik berfungsi antara lain area informasi, area tunggu, area penerima tamu, area layanan dan area sekuriti. Bentuk dan jenis area tersebut sangat tergantung pada karakter kantor/kedinasan. Terdapat fenomena bahwa adanya layanan satu atap, yaitu terdapat 2 atau lebih jenis kantor/kedinasan dalam satu bangunan gedung. Hal ini menjadi menarik, karena masing masing memiliki karakter layanan yang berbeda, namun dalam satu ruang layanan publik. Jenis layanan yang beragam yang terjadi di satu ruang di ruang layanan publik, sering menimbulkan disorientasi sebagai dampak dari ketidak efektifan penggunaan ruang. Penelitian ini bertujuan merumuskan pola okupansi dan attachment pengunjung di ruang layanan publik kantor PDAM Surya Sembada kota Surabaya, untuk menjadi row model penataan area dan penggunaan ruang. Penelitian dilakukan dengan cara observasi perilaku melalui rekam jejak guna mencermati pola aktivitas yang terjadi. Wawancara digunakan utuk melengkapi data. Rumusan Pola okupansi dan attachment pengunjung di ruang layanan publik kantor PDAM Surabaya diharapkan menjadi row model smart performance public space untuk keberlangsungan/sustainable environment. Luaran penelitian ini berupa paper yang dipublikasikan di jurnal nasional.
\end{abstract}

Kata kunci: attachment; okupansi; smart public space

\section{PENDAHULUAN}

Ruang layanan publik kantor identik dengan pintu gerbang imej layanan. Secara umum ruang layanan publik berfungsi antara lain area informasi, area tunggu, area penerima tamu, area layanan dan area sekuriti. Bentuk dan jenis area tersebut sangat tergantung pada karakter kantor/kedinasan. Terdapat fenomena bahwa adanya layanan satu atap, yaitu terdapat 2 atau lebih jenis kantor/kedinasan dalam satu bangunan gedung. Hal ini menjadi menarik, karena masing masing memiliki karakter layanan yang berbeda, namun dalam satu ruang layanan publik. Jenis layanan yang beragam yang terjadi di satu ruang di ruang layanan publik sering menimbulkan disorientasi sebagai dampak dari ketidak efektifan penggunaan ruang. Penelitian ini bertujuan merumuskan pola okupansi dan attachment pengunjung di ruang layanan publik kantor kedinasan, untuk menjadi modul penataan area dan penggunaan ruang.

Okupansi adalah salah satu bentuk perilaku dalam upaya kepemilikan teritori. Altman (1980) menyebut sebagai a territorial claim. Ekspresi dan eksistensi teritori sebagai wujud okupansi ditandai dengan adanya display atau sign, misalnya dinding, taman, papan nama, karpet, dan sebagainya. Dirumuskan bahwa terdapat 3 elemen dasar dalam memahami okupansi, yaitu orang/pengguna, tempat atau ruang serta tanda (sign penggunaan tempat/ruang). Pada umumnya okupansi ditandai dengan adanya pembatas secara fisik, misalnya pagar, pintu, dinding dan lain lain.

Attachment atau keterikatan pada suatu tempat adalah kebutuhan mendapatkan kedekatan pada suatu tempat untuk alasan kenyamanan, keselamatan, keamanan dan perlindungan. Bowlby (1982) dalam Prakoso Susinety (2015), pada dasarnya setiap orang mempunyai 
pengalaman emosi dengan tempat tertentu, baik yang menyenangkan maupun tidak menyenangkan. Adapun tempat yang dimaksud adalah tempat dimana melakukan aktivitas. Pada penelitian sebelumnya, Scannell dan Gifford (2010) menjabarkan tripartite model of place attachment. Sebuah kerangka organisasi yang terdiri atas 3 dimensi yang terpisah, namun saling melengkapi dalam memahami place attachment, yaitu dimensi orang/pengguna, proses dan tempat. Scannell dan Gifford (2010) mengartikan tempat pada kajian fisik dan sosial. Fisik sebagai wujud lingkungan binaan, Haryadi dan Setiawan (1995) lebih lanjut menjabarkan dalam istilah behavior setting, yaitu system of setting dan system of activity. System of setting adalah sistem rangkaian elemen elemen fisikal dan spasial dalam hubungan tertentu yang saling terkait digunakan untuk kegiatan tertentu. sedangkan sosial sebagai fungsi simbol atau arena/sarana sosial.

Penelitian dilakukan di kantor PDAM Swa Sembada Surabaya. Kantor tersebut dipilih sebagai row model juga sebagai studi kasus yang merepresentasikan fenomena perilaku okupansi dan attachment di area layanan publik. Berhubung adanya pandemi Covid 19, maka metode penelitian observasi perilaku lebih dibantu dengan rekam jejak, guna mencermati pola aktivitas yang terjadi. Wawancara dengan pengguna dilakukan secara daring untuk melengkapi data. Rumusan pola okupansi dan attachment pengunjung di ruang layanan publik kantor PDAM Surabaya tersebut diharapkan menjadi salah satu row model smart performance public space untuk keberlangsungan/sustainable environment, khususnya di lingkungan interior. Berikut beberapa fenomena yang diangkat, yaitu:

- Identitas. Sebagai ruang yang berfungsi layanan publik, maka identitas tentang jenis dan tempat/lokasi layanan harus mudah ditangkap dan dipahami. Kemudahan tidak hanya tentang adanya informasi, namun perlu desain identitas untuk mempertegas corporate

- Attachment. Keterikatan secara non fisik pengguna pada area layanan publik sebaiknya dapat dicapai karena sarana prasarana harus sesuai dengan karakter fungsi dan aktivitas. Diperlukan prioritas dan pemetaan fungsi layanan publik sehingga memudahkan dalam meng akses dan runut

- Okupansi. Keterikatan secara fisik terhadap fasilitas publik tidak hanya secara fungsi, namun juga secara non fisik.

Penelitian ini sangat berkaitan dengan Environment and Behavior Studies (EBS). Sebuah pendekatan studi perilaku terhadap lingkungannya. Utamanya tentang teori okupansi dan attachment pada suatu ruang. Penelitian ini bertujuan merumuskan design requirement untuk Smart Performance Public Space kantor/kedinasan di kota Surabaya.

\section{METODE PENELITIAN}

Penelitian ini merupakan penelitian kualitatif dengan strategi pengumpulan data secara observing behavior, observing physical traces, dan wawancara terstruktur (Zeisel, 1984). Penelitian ini lebih menekankan serta mengandalkan pada strategi tracer observing behavior. Traces/pengamatan jejak fisik dilakukan berdasarkan hasil observasi langsung. Observasi langsung dilakukan saat sebelum pandemi Covid-19. Berhubung tahap berikutnya terdapat protokol kesehatan yang berdampak pada sistem layanan yaitu lebih ke pelayanan online, maka tidak lagi dapat melakukan observasi langsung. Langkah pengumpulan data dilanjutkan dengan pengamatan jejak fisik, yaitu melalui data gambar kerja dan gambar 3D suasana dari pihak perencana dan nara sumber. Aspek yang diamati sebagai berikut:

- Susunan atau layout ruang. Pengamatan layout ruang memberi gambaran guna melakukan hubungan ruang, sirkulasi, pembagian/zoning area layanan, pola evakuasi, serta aksesibilitas. 
- Susunan atau layout furnitur. Pengamatan pada susunan layout furnitur memberi gambaran tentang okupansi dan keterikatan pengguna pada setting/place/area yang dituju.

- Sistem atau alur layanan di setiap jenis layanan, yang akan menjadi aspek yang dikaitkan dengan kesesuaian penggunaan ruang.

- Kemudahan okupansi serta tingkat kenyamanan keterikatan pada suatu tempat.

Penelitian ini merupakan penelitian tentang perilaku yang dibentuk dan mempengaruhi kualitas lingkungannya (interior). Menurut Rapoport (1986), lingkungan fisik dapat menentukan perilaku manusia (environmental determinism), lingkungan fisik menyediakan batas yang di dalamnya manusia dapat memilih (environmental possibilism) atau lingkungan fisik menyediakan pilihan. Fenomena perilaku angat berkaitan dengan setting tempat/place. Karena fenomena perilaku dan pola perilaku pengguna pada setting place tertentu membentuk hubungan timbal-balik yang mempengaruhi kualitas pengguna maupun place/lingkungannya.

Pengamatan perilaku bertujuan mengetahui keterikatan fenomena behavior dengan wujud fisik/setting perancangan fisiknya. Pengamatan perilaku dilakukan secara behvaior mapping, yang meliputi kebutuhan data: denah, sistem layanan, sirkulasi pengguna (posisi, alur/pola, jarak dan konsentrasi pengguna) serta tanda/simbol.

Pengamatan jejak fisik. bertujuan mengetahui keadaan pada setting guna memperkirakan aktivitas yang terjadi. Hasil pengamatan jejak fisik ini berupa foto, catatan, atau video. Pengamatan jejak fisik ini diterapkan secara dominan dalam penelitian kali ini, karena keterbatasan pengamatan perilaku yang secara langsung, sehubungan masih dalam kondisi pandemi Covid-19.

Wawancara. dilakukan setelah memperoleh jejak fisik. Tujuannya dapat melengkapi kebutuhan data serta alasan terjadinya fenomena perilaku terssebut. Wawancara dilakukan terhadap staf kantor PDAM dan pengguna.

\section{HASIL DAN DISKUSI}

\section{A. KARAKTER LAYANAN}

Terdapat 5 jenis layanan di ruang publik kantor PDAM Surabaya. Adapun jenis serta alur layanannya secara luring/offline adalah sebagai berikut:

a. Layanan Pembayaran

Tahapan untuk melakukan pembayaran rekening adalah sebagai berikut.

1) Pengunjung mengambil nomor antrian.

2) Menunggu panggilan di area tunggu loket pembayaran-customer service.

3) Dipanggil ke loket pembayaran.

Gambar 1 berikut adalah denah layout dan zona alur pembayaran

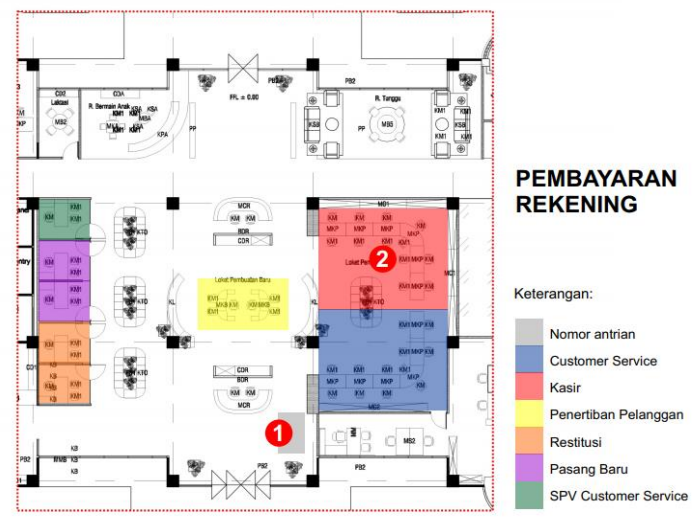

Gambar 1. Layout dan blocking zona alur pembayaran 
Susy Budi Astuti ${ }^{1}$, Mahendra Wardhana ${ }^{2}$, Prasetyo Wahyudie ${ }^{3}$, Lea Kristina Anggraeni ${ }^{4}$

Pola Penataan Ruang Layanan Publik yang Smart, Berdasarkan Kajian Okupansi dan Attachment Pengguna

(Objek Kasus : Ruang Layanan Publik di Kantor / Dinas di Pemerintah Kota Surabaya)

b. Layanan Pelanggan

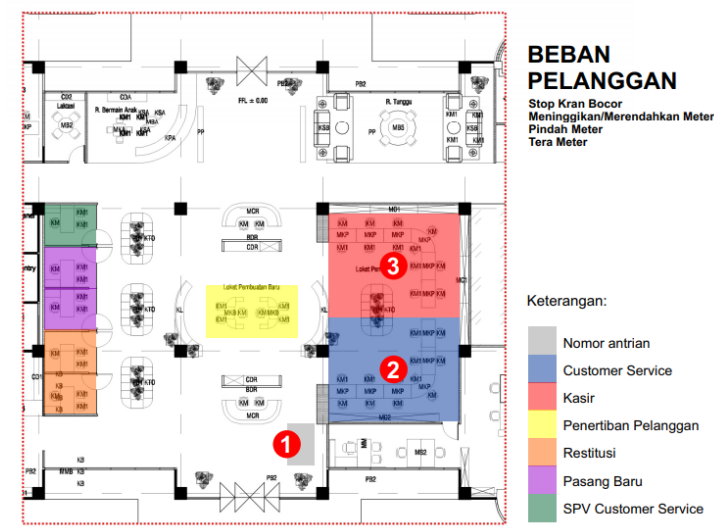

Gambar 2. Layout dan blocking zona alur pelayanan masalah beban pelanggan

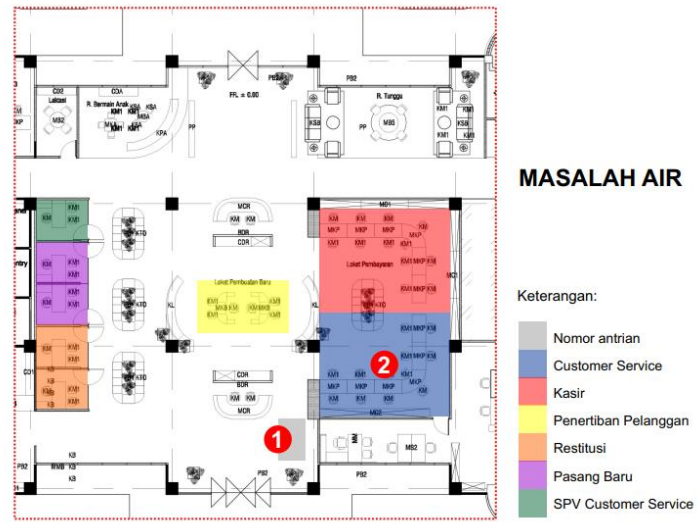

Gambar 3. Layout dan blocking zona alur pelayanan masalah air

Tahapan untuk melayani pengaduan beban pelanggan (kran air bocor, pindah meter, tera meter, dan meninggikan/merendahkan meter) dan masalah air, adalah sebagai berikut.

1) Pengunjung mengambil nomor antrian.

2) Menunggu panggilan di area tunggu loket pembayaran-customer service.

3) Dipanggil ke loket customer service.

4) Menunggu panggilan di area tunggu loket pembayaran-customer service.

5) Dipanggil ke loket pembayaran 
c. Layanan Restitusi

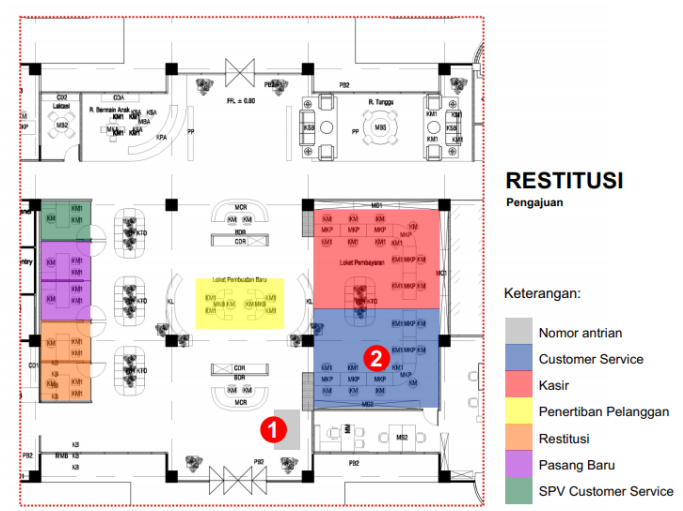

Gambar 4. Layout dan blocking zona alur pengajuan restitusi

Terdapat 2 tahapan layanan restitusi,yaitu pengajuan dan pengambilan restitusi.

Tahapan untuk melakukan pengajuan restitusi adalah sebagai berikut.

1) Pengunjung mengambil nomor antrian.

2) Menunggu panggilan di area tunggu loket pembayaran-customer service.

3) Dipanggil ke loket customer service.
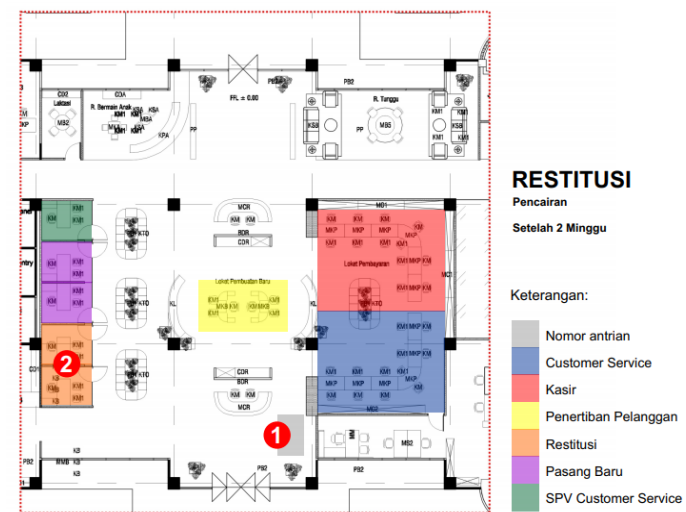

Gambar 5. Layout dan blocking zona alur pengambilan restitusi

Tahapan untuk melakukan pengambila restitusi adalah sebagai berikut.

1) Pengunjung mengambil nomor antrian.

2) Menunggu panggilan di area tunggu loket restitusi.

3) Dipanggil ke loket restitusi.

d. Layanan Tutupan Dinas

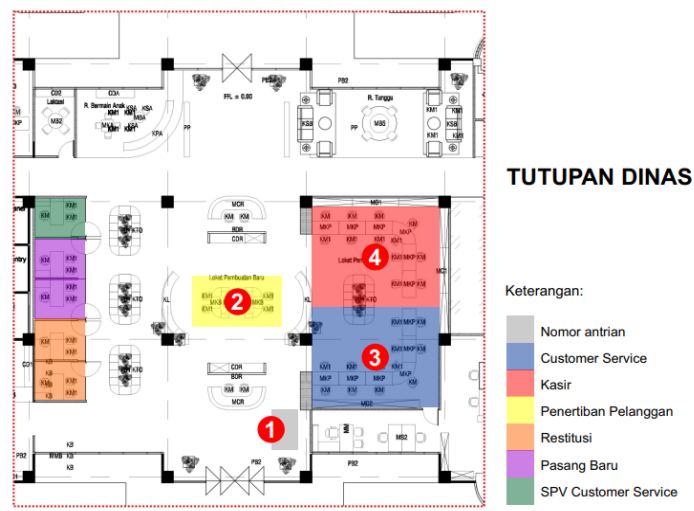

Gambar 6. Layout dan blocking zona alur tutupan dinas 
Susy Budi Astuti ${ }^{1}$, Mahendra Wardhana ${ }^{2}$, Prasetyo Wahyudie ${ }^{3}$, Lea Kristina Anggraeni ${ }^{4}$ Pola Penataan Ruang Layanan Publik yang Smart, Berdasarkan Kajian Okupansi dan Attachment Pengguna (Objek Kasus : Ruang Layanan Publik di Kantor / Dinas di Pemerintah Kota Surabaya)

Tahapan untuk melakukan tutupan dinas adalah sebagai berikut.

1) Pengunjung mengambil nomor antrian.

2) Menunggu panggilan di area tunggu loket penertiban pelanggan.

3) Dipanggil ke loket penertiban pelanggan.

4) Menunggu panggilan di area tunggu loket pembayaran-customer service.

5) Dipanggil ke loket customer service.

6) Kembali menunggu panggilan di area tunggu loket pembayaran-customer service.

7) Dipanggil ke loket pembayaran.

e. Layanan Pasang Baru

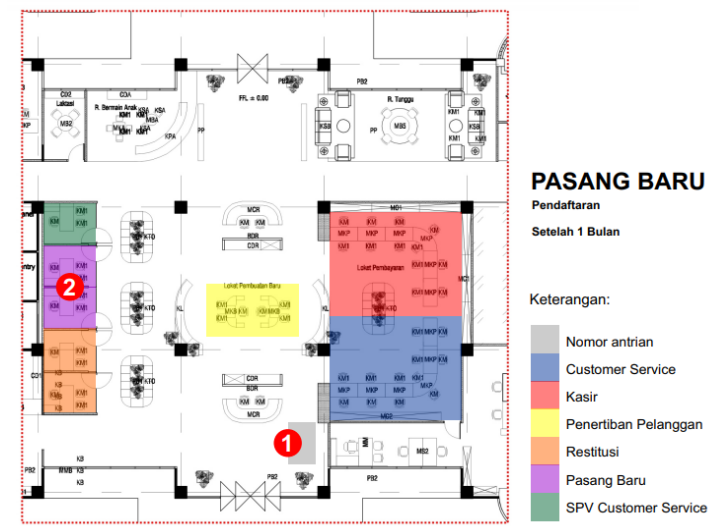

Gambar 7. Layout dan blocking zona alur pendaftaran pasang baru

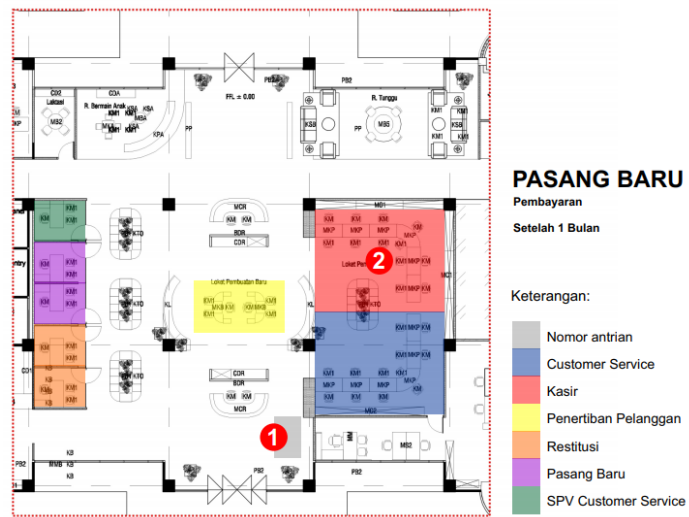

Gambar 8. Layout dan blocking zona alur pembayaran pasang baru

Tahapan untuk melakukan pendaftaran dan pembayaran pasang baru adalah sebagai berikut.

1) Pengunjung mengambil nomor antrian.

2) Menunggu panggilan di area tunggu loket pasang baru.

3) Dipanggil ke loket pasang baru.

Berdasarkan profil sistem layanan di kantor PDAM Surya Sembada Surabaya tersebut, maka diperoleh peta dan pola urutan aktivitas layanan yang harus dilakukan oleh pelanggan/pengguna ketika menggunakan ruang layanan publik, yaitu seperti tersaji pada tabel 1 berikut. 
Tabel 1. Jenis, Pola/Sistem Layanan di Ruang Publik Kantor PDAM

\begin{tabular}{|c|c|c|c|c|c|c|c|c|c|c|c|c|c|}
\hline \multirow[t]{2}{*}{$\begin{array}{l}\mathrm{N} \\
\mathrm{O}\end{array}$} & \multirow{2}{*}{\multicolumn{2}{|c|}{ Jenis Layanan }} & \multirow{2}{*}{$\begin{array}{c}\text { No } \\
\text { Antrian } \\
\text { Loket no } \\
\text { antrian }\end{array}$} & \multicolumn{2}{|c|}{$\begin{array}{l}\text { Costumer } \\
\text { Service } \\
\text { (CS) }\end{array}$} & \multicolumn{2}{|c|}{$\begin{array}{c}\text { Kasir } \\
\text { (Pembayaran) }\end{array}$} & \multicolumn{2}{|c|}{ Restitusi } & \multicolumn{2}{|c|}{ Pelanggan } & \multicolumn{2}{|c|}{ Pasang Baru } \\
\hline & & & & $\begin{array}{c}\text { area } \\
\text { tunggu }\end{array}$ & $\begin{array}{c}\text { Area } \\
\text { CS }\end{array}$ & $\begin{array}{c}\text { Area } \\
\text { tunggu }\end{array}$ & $\begin{array}{l}\text { Loket } \\
\text { kasir }\end{array}$ & $\begin{array}{c}\text { Area } \\
\text { tunggu }\end{array}$ & $\begin{array}{c}\text { Loket } \\
\text { restitusi }\end{array}$ & $\begin{array}{c}\text { Area } \\
\text { tunggu }\end{array}$ & $\begin{array}{c}\text { Loket } \\
\text { Penertipan } \\
\text { pelanggan }\end{array}$ & $\begin{array}{c}\text { Area } \\
\text { tunggu }\end{array}$ & $\begin{array}{c}\text { Loket } \\
\text { Pasang } \\
\text { baru }\end{array}$ \\
\hline 1 & \multicolumn{2}{|c|}{ Pembayaran } & 1 & & & 2 & 3 & & & & & & \\
\hline 2 & \multicolumn{2}{|c|}{ Pengaduan } & 1 & 2 & 3 & 4 & 5 & & & & & & \\
\hline \multirow[t]{2}{*}{3} & \multirow[t]{2}{*}{ Restitusi } & \begin{tabular}{|l|} 
Pengajuan \\
\end{tabular} & 1 & 2 & 3 & & & & & & & & \\
\hline & & $\begin{array}{l}\text { Pengambilan } \\
\end{array}$ & 4 & & & & & 5 & 6 & & & & \\
\hline 4 & \multicolumn{2}{|c|}{ Tutupan Dinas } & 1 & 4 & 5 & 6 & 7 & & & 2 & 3 & & \\
\hline 5 & \multicolumn{2}{|c|}{ Pasang Baru } & 1 & & & 4 & 5 & & & & & 2 & 3 \\
\hline
\end{tabular}

Keterangan: Nomor menunjukan urutan alur/proses layanan

\section{B. OKUPANSI: PENGGUNA, TEMPAT, DAN TANDA}

Okupansi pengguna terhadap tempat menunjukkan bahwa di area loket pengambilan nomor antrian, area kasir dan area customer service merupakan area yang paling dominan dikunjungi. Penggunaan ke 3 area tempat tersebut menjadi cermin layanan utama yang selalu diokupansi oleh pengguna. Hal tersebut ditandai dengan penyatuan area customer service dengan area kasir (pembayaran), yaitu dalam satu zona. Tingkat okupansi yang tinggi pada area customer service dan kasir, serta berurutan proses layanannya menjadi pertimbangan dalam penataan blocking area, yaitu open space. Secara kuantitas, layanan pengaduan paling banyak pengunjungnya, sehingga paling banyak 'menyumbang' okupansi di area customer service dan area kasir

Namun, pada area tersebut terdapat perbandingan jumlah loket dan jumlah kursi tunggu yang tidak sesuai dengan kebutuhan. Hanya ada 14 kursi tunggu untuk 12 loket layanan pada area loket pembayaran dan customer service. Okupansi pada loket pembayaran dan customer service sudah sangat mewadahi layanan secara cepat. Namun terdapat fenomena bahwa pengguna menggunakan area tunggu tidak hanya saat menunggu, namun juga untuk beristirahat sejenak untuk memeriksa kembali berkas berkas setelah dari loket pembayaran/customer service.

Okupansi area tunggu menjadi berfungsi ganda yaitu untuk menunggu dan memeriksa berkas setelah transaksi. Tanda okupansi ganda pada area tunggu adalah keberadaan pengguna secara bersama-sama antara yang menunggu dan yang istirahat memeriksa berkas, sehingga kursi di area tunggu selalu penuh. Berikut fenomena okupansi pengguna pada area layanan pembayaran/kasir dan customer service.

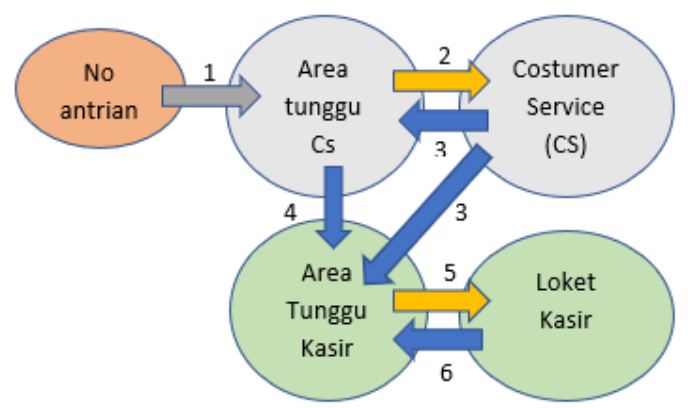

Gambar 9. Alur dan blocking zona area customer service dan pembayaran/kasir

\section{ATTACHMENT/KETERIKATAN: PENGGUNA, TEMPAT, DAN PROSESN}

Attachment atau keterikatan pengguna terhadap tempat sangat berkaitan dengan sistem atau proses alur layanan. Terdapat 5 jenis layanan yang berbeda alur/proses yang diterapkan. 
Susy Budi Astuti ${ }^{1}$, Mahendra Wardhana ${ }^{2}$, Prasetyo Wahyudie ${ }^{3}$, Lea Kristina Anggraeni ${ }^{4}$

Pola Penataan Ruang Layanan Publik yang Smart, Berdasarkan Kajian Okupansi dan Attachment Pengguna

(Objek Kasus : Ruang Layanan Publik di Kantor / Dinas di Pemerintah Kota Surabaya)

Tabel 2. Jenis, Pola/Sistem Layanan di Ruang Publik Kantor PDAM Surabaya

\begin{tabular}{|c|c|c|c|c|c|c|c|c|c|c|c|c|c|c|}
\hline \multirow[t]{2}{*}{\begin{tabular}{l|l}
$\mathrm{N}$ \\
$\mathrm{O}$
\end{tabular}} & \multirow{2}{*}{\multicolumn{2}{|c|}{ Jenis Layanan }} & \multirow{2}{*}{$\begin{array}{c}\begin{array}{c}\text { No } \\
\text { Antrian }\end{array} \\
\begin{array}{c}\text { Loket no } \\
\text { antrian }\end{array}\end{array}$} & \multicolumn{2}{|c|}{$\begin{array}{l}\text { Costumer } \\
\text { Service } \\
\text { (CS) }\end{array}$} & \multicolumn{2}{|c|}{$\begin{array}{c}\text { Kasir } \\
\text { (Pembayaran) }\end{array}$} & \multicolumn{2}{|c|}{ Restitusi } & \multicolumn{2}{|c|}{ Pelanggan } & \multicolumn{2}{|c|}{ Pasang Baru } & \multirow{2}{*}{$\begin{array}{c}\text { Jumlah } \\
\text { pengun } \\
\text { jung } \\
\text { skala } \\
1-5 \\
\end{array}$} \\
\hline & & & & \begin{tabular}{c|} 
area \\
tunggu
\end{tabular} & $\begin{array}{l}\text { Area } \\
\text { cs }\end{array}$ & \begin{tabular}{|c|} 
Area \\
tunggu \\
\end{tabular} & $\begin{array}{l}\text { Loket } \\
\text { kasir }\end{array}$ & \begin{tabular}{c|} 
Area \\
tunggu
\end{tabular} & $\begin{array}{l}\text { Loket } \\
\text { restitusi }\end{array}$ & $\begin{array}{l}\text { Area } \\
\text { tunggu }\end{array}$ & $\begin{array}{c}\text { Loket } \\
\text { Penertipan } \\
\text { pelanggan }\end{array}$ & \begin{tabular}{|l|} 
Area \\
tunggu
\end{tabular} & \begin{tabular}{c|} 
Loket \\
Pasang \\
baru
\end{tabular} & \\
\hline 1 & \multirow{2}{*}{\multicolumn{2}{|c|}{\begin{tabular}{|l} 
Pembayaran \\
\end{tabular}}} & 1 & & & 2 & 3 & & & & & & & 3 \\
\hline 2 & & Pengaduan & 1 & 2 & 3 & 4 & 5 & & & & & & & 5 \\
\hline \multirow[t]{2}{*}{3} & \begin{tabular}{|l|} 
Restitusi \\
\end{tabular} & Pengajuan & 1 & 2 & 3 & & & & & & & & & \multirow[t]{2}{*}{2} \\
\hline & & Pengambilan & 4 & & & & & 5 & 6 & & & & & \\
\hline \multirow{3}{*}{$\frac{4}{5}$} & \multirow{2}{*}{\multicolumn{2}{|c|}{$\begin{array}{l}\text { Tutupan Dinas } \\
\text { Pasang Baru }\end{array}$}} & 1 & 4 & 5 & 6 & 7 & & & 2 & 3 & & & 4 \\
\hline & & & 1 & & & 4 & 5 & & & & & 2 & 3 & 1 \\
\hline & \multicolumn{2}{|c|}{$\begin{array}{l}\text { Intensitas keterikatan } \\
\text { pada tempat terhadap } \\
\text { keseluruhan ienis } \\
\text { layanan PDAM }\end{array}$} & $100 \%$ & \multicolumn{2}{|c|}{$80 \%$} & \multicolumn{2}{|c|}{$90 \%$} & \multicolumn{2}{|c|}{$10 \%$} & & $10 \%$ & \multicolumn{2}{|c|}{$10 \%$} & \\
\hline
\end{tabular}

Berdasarkan tabel 2 di atas nampak bahwa semua jenis layanan melewati layanan pendaftaran, pembayaran/kasir dan customer service. Keterikatan pada layanan pendaftaran (nomor antrian) sebesar $100 \%$, layanan pembayaran $90 \%$ dan customer service $80 \%$. Perhitungan tersebut berdasarkan tahapan yang harus dilalui dalam proses di semua jenis layanan. Artinya bahwa semua jenis layanan pada ruang publik, harus memiliki nomor antrian terlebih dahulu, sehingga memiliki keterikatan penuh (100\%) pada loket pendaftaran. Khusus layanan restitusi tidak memanfaatkan pembayaran di kasir, karena proses restitusi (pengembalian dana dari PDAM ke pelanggan) langsung dilakukan oleh petugas restitusi.

Berdasarkan hal tersebut, maka keterikatan pada penggunaan area pendaftaran/pengambilan nomor antrian, customer service dan pembayaran menjadi 3 area dominan dalam proses layanan yang digunakan pengguna. Selain ada proses yang dominan terjadi tersebut, kontribusi jumlah pengguna menjadi hal yang memperkuat tanda keterikatan pengguna. Layanan pengaduan (dalam tabel 2.2.) menempati level tertinggi jumlah penggunanya, yaitu level 5 (teratas). Selanjutnya layanan tutupan dinas pada level 4, pembayaran pada level 3, kemudian restitusi pada level 2, terakhir pasang baru.

Bila ditinjau dari fenomena tersebut maka keterikatan pengguna yang membutuhkan layanan pengaduan dan tutupan dinas akan sangat terkait erat dengan setting tempat 3 area dominan.

Kedua layanan tersebut berada pada zona sebelah sisi kanan seperti pada gambar berikut.

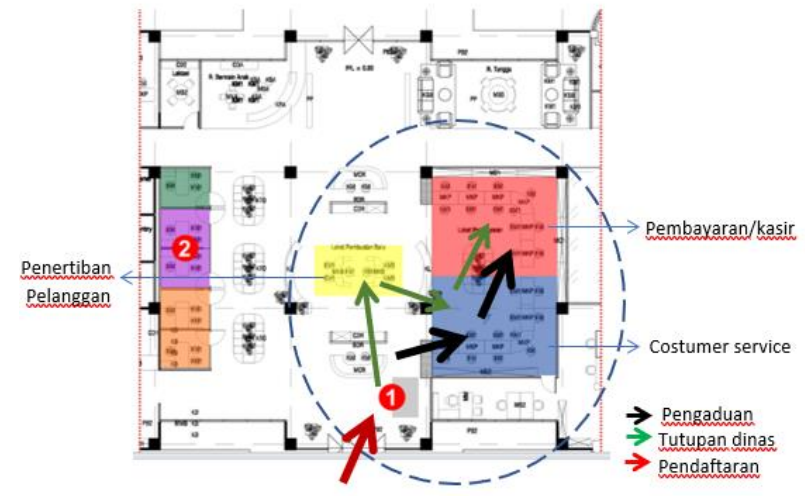

Gambar 10. Keterikatan layanan pada proses pengaduan dan tutupan dinas.

Keterikatan proses layanan pengaduan terhadap 3 loket (pendaftaran, CS dan Kasir) dan tutupan dinas terhadap 4 loket (pendaftaran, penertiban pelanggan, CS dan Kasir) yang berada pada zona yang berdekatan menimbulkan irisan penggunaan area sehingga terjadi titik 
konsentrasi/berjubelnya pengguna pada satu area. Fenomena ini memberi makna bahwa area tunggu menjadi 'place' yang penting dan mengikat proses.

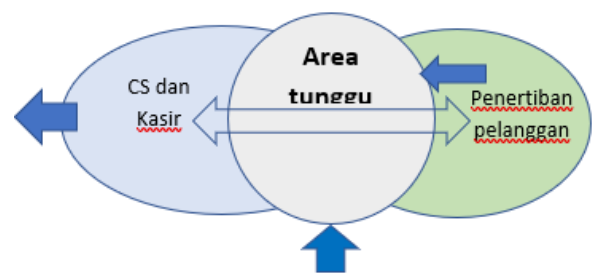

Gambar 11. Skema alur layanan yang didominasi oleh keterikatan pada area tunggu
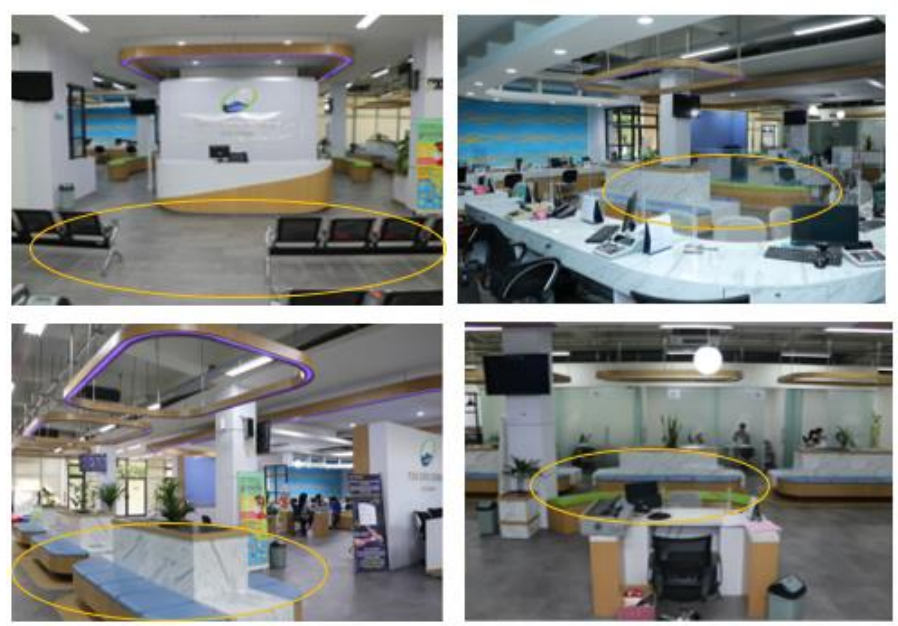

Gambar 12. Eksistensi area tunggu sebagai tanda keterikatan layanan di semua jenis layanan

Area tunggu menjadi tanda keberadaan loket layanan untuk semua jenis layanan. Karakter ruang yang open space, membuat ruang berkesan luas. Namun dapat menjadi hal yang menyebabkan disorientasi bagi pengguna. Disorientasi terjadi karena ruang cukup luas, simetris tatanan layout-nya, serta memiliki nuansa interior yang sama. Area tunggu menjadi space yang mengikat dan tempat tersedianya tanda/identitas jenis layanan. Karena sumber informasi berada atau diletakan di area tunggu.

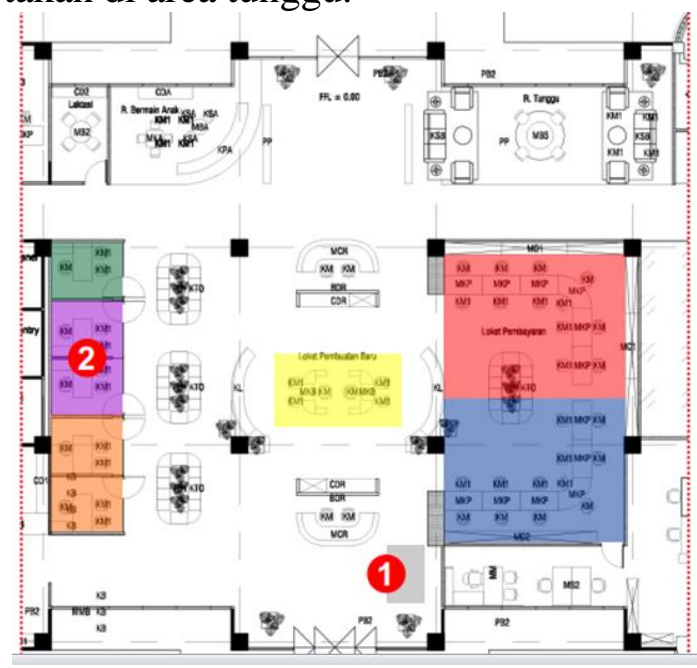

Gambar 13. Blocking zona area tunggu pada setiap jenis layanan

\section{KESIMPULAN}

Ruang layanan publik adalah setting tempat untuk mewadahi pengguna dalam sistem layanan tertentu. Fenomena ruang layanan yang smart pada kantor PDAM kota Surabaya, dalam penelitian ini ditinjau terhadap keterkaitan perilaku dan lingkungannya, yaitu sistem 
layanan terhadap setting/desain ruang layanan publiknya. Smart sistem layanan sangat mempengaruhi desain setting tempat, demikian pula sebaliknya desain setting tempat juga mempengaruhi sistem layanan. Pengguna sebagai pelaku di ruang publik merespon hubungan timbal balik tersebut berdasarkan fenomena perilaku yang terjadi.

Berdasarkan hasil pembahasan, maka smart performance ruang layanan publik adalah sebagai berikut:

1. Aspek Okupansi. Aspek okupansi pada ruang layanan publik selain harus mempertimbangkan tempat dan tanda okupansi, harus pula mempertimbangkan karakter aktivitas pengguna. Setting tempat okupansi tidak hanya didesain secara fisik saja sebagai peruntukan fungsi (mis. kursi di area tunggu, meja kursi di area kasir dll.) namun juga mempertimbangkan karakter aktivitas pengguna. Terdapat kecenderungan bahwa tingkat okupansi tidak hanya terjadi di pra-pelayanan (menunggu), namun juga di post pelayanan (memeriksa berkas/istirahat). Smart ruang layanan publik ditandai oleh representasi/performance area tunggu. Intensitas okupansi area tunggu menjadi cermin smart layanan. Smart layanan memiliki keseimbangan intensitas okupansi pada area tunggu dengan intensitas layanan di area loket/customer service.

2. Aspek Attachment/Keterikatan. Aspek keterikatan pada ruang layanan publik sangat berkaitan dengan proses/karakter sistem layanan. Sebagai kantor layanan publik dengan berbagai jenis layanan yang dimiliki, maka harus dipetakan semua proses layanan yang terjadi. Terdapat fenomena bahwa beberapa proses layanan memiliki alur yang sama. Sehingga terdapat keterikatan pada proses yang sama walaupun jenis layanan yang berbeda. Hal tersebut menjadi fenomena adanya keterikatan yang erat antara tempat/place dengan proses. Proses yang sama pada beberapa jenis layanan, memberi makna bahwa desain tempat 'place' untuk kepentingan bersama dan terjadi secara dominan tersebut, merupakan keterikatan besar yang mengikat semua proses layanan.

\section{DAFTAR PUSTAKA}

Altman, I dan Chemers, M. (1980), Culture and Environment, Monterey, California Farida (2013),"Effect of Outdoor Shared Spaces on Social Interaction in Housing Estate in Algeria", Frontier of Architectural Research (2013), Vol.2, Hal. 457-467

Hunt, B. (2001),"Sustainable Placemaking", a keynote speech of sustainable place making forum 2001, dikutip dari http://www.sustainable-placemaking.org/about.htm

Kinney, J. M., Stephens, M. A. P., McNeer, A. E. \& Murphy, M. R. (1985),” Personalization of Private Spaces in Congregate Housing for Older People, dalam Environmental Change/Social Change. eds. Klein, S., Wener, R. \& Lehman, S, Washington D.C, EDRA.

Lang, J \& Moleski Walter (2010), Functionalism Revisited, Ashgate Publishing Limited, England

Prakoso, Susinety (2015), Place Habit Sebagai Fenomena Kehadiran Kelekatan Anak Pada Tempat, Fakultas Teknik Program Doktor Arsitektur, Universitas Indonesia, DepokJakarta

Scannell, L dan Gifford, R (2010), "Defining Place Attachment : A Tripartite Organizing Framework", Journal of Environmental Psychology, Vol.30(1), Hal. 1-10.

Zeisel, John (1984), Inquiry by Design : Tools For Environment-Behavior Research, Cambridge University Press, Cambridge 